Gašper Cerkovnik

\title{
Hortuli animae iz let 1516 in 1548 v Narodni in univerzitetni knjižnici $v$ Ljubljani: predreformacijski molitvenik in njegova luteranska transformacija
}

\begin{abstract}
Ključne besede: Hortulus animae, Narodna in univerzitetna knjižnica v Ljubljani, lesorezne ilustracije, predreformacijska pobožnost, protestantska pobožnost, Lukas Cranach st., Georg Rhau
\end{abstract}

V Zbirki starih tiskov slovenske Narodne univerzitetne knjižnice v Ljubljani (NUK) hranijo dva nemška molitvenika $\mathrm{z}$ enakim naslovom Hortulus animae iz prve polovice 16. stoletja $\mathrm{v}$ formatu oktava. Obe knjižici sta tiskani $\mathrm{v}$ črni barvi s posameznimi rdečimi poudarki, posamezne iniciale ter številne ilustracije pa so izvedene $\mathrm{v}$ tehniki lesoreza. Medtem ko sta si molitvenika na prvi pogled zelo podobna, že letnica in kraj izdaje nakazujeta nekaj pomembnih razlik: prvi molitvenik je bil natisnjen $\mathrm{v}$ latinščini v Mainzu leta 1516 (GS 0 12950), torej leto pred Lutrovim »pribitjem« 95 tez na vrata stolnice $\mathrm{v}$ Wittenbergu, kjer je bil leta 1548, ko je veljalo to mesto za enega od najpomembnejših središč nove Lutrove vere, ${ }^{1}$ izdan drugi molitvenik (GS 0 13829). V prvem primeru gre za predreformacijski molitvenik, $v$ drugem pa za protestantskega. Oba izvoda do sedaj še nista bila deležna veliko pozornosti, v tuji strokovni literaturi pa so tiski tega tipa praviloma obravnavani zaradi svojega likovnega okrasa. Zaradi različnih okoliščin nastanka sta molitvenika $\mathrm{v}$ NUK-ovi zbirki idealna osnova za primerjavo odnosa med teksti in knjižnimi ilustracijami $\mathrm{v}$ predreformacijskih in reformacijskih molitvenikih.

Običajno latinsko naslovljeni molitvenik Hortulus animae sodi med najbolj priljubljene molitvenike poznega srednjega veka in zgodnjega novega veka $\mathrm{v}$ Srednji Evropi, posebno $\mathrm{v}$ nemških deželah. Od prve znane latinske izdaje iz leta 1498 v Strasbourgu je - kot je ugotovila ena pomembnejših raziskovalk ilustriranih tiskanih knjig tega področja in časa Maria Consuelo Oldenbourg do okoli leta 1520 izšlo več kot sto različnih izdaj v latinščini, nemščini, češčini in srednjenizozemskem jeziku (Oldenbourg, 1973, 5). Hortuli so v svoji strukturi ohranili veliko značilnosti horarijev kot najbolj priljubljenega in razširjenega

1 Wittenberg se še danes uradno imenuje Lutherstadt Wittenberg. Za specifične zgodovinske okoliščine ob nastanku tega molitvenika gl. Hühns (1977). 
laičnega molitvenika poznega srednjega veka, vendar je ta izdaja močno predelana in prilagojena srednjeevropskim religioznim predstavam. Poleg različne izbire in razvrstitve molitev je razlika med horarijem in molitvenikom "Hortulus animae" najopaznejša pri odnosu do likovnega okrasa, ki je v slednjih občutno skromnejši in vedno podrejen tekstu. Glede na številne ilustracije sicer ni nobenega dvoma, da so bile nepogrešljive, $\mathrm{z}$ vidika horarijev pa preseneča na prvi pogled nizka zavest o slogovni in kakovostni enotnosti uporabljenih lesorezov. Med založniki in tiskarji teh molitvenikov je do ilustracij očitno prevladoval zelo pragmatičen odnos, saj so v posameznih izdajah molitvenikov praviloma brez zadržkov uporabili ilustracije, ki se niso ujemale ne v velikosti, času nastanka, avtorstvu ali kakovosti (Oldenbourg, 1972, 71-133). Neobčutljivost založnikov brez dvoma odseva tudi pričakovanja in zahteve uporabnikov ter posledično neambicioznost izdelovalcev lesoreznih ilustracij. Glede na okoliščine tiskanja in uspešno prodajo ilustriranih molitvenikov je izdelava praviloma dokaj majhnih, preprostih, a številnih ilustracij tudi za uveljavljene umetnike predstavljala razmeroma udoben vir zaslužka, za številne manjše mojstre pa verjetno celo precej zanesljiv in stalen vir dohodkov. $\mathrm{Ne}$ glede na to pa bi bilo podcenjevanje teh drobnih ilustriranih molitvenikov zmotno, saj lahko z njimi povežemo kar nekaj najpomembnejših osebnosti te dobe. Vsaj pri nemškem prevodu, mogoče pa že pri nastanku latinskega izvirnika, je sodeloval slavni nemški humanist Sabastian Brant, ${ }^{2}$ lesorezne serije za molitvenike tega časa pa so prispevali skoraj vsi najpomembnejši nemški umetniki, kot na primer Albrecht Dürer, Hans Burgkmair st., Lukas Cranach st. in Hans Holbain ml. V tem žanru so se uspešno preizkusili tudi Hans Baldung, imenovan Grien, Hans Schäufelein in Hans Springinklee. Glede na našteta imena in izrazito eklektične tekstovne sestave teh molitvenikov ne preseneča, da so bili praviloma deležni pozornosti predvsem $\mathrm{s}$ strani umetnostnih zgodovinarjev. ${ }^{3}$ Kljub temu so posamezne raziskave, usmerjene predvsem v predreformacijsko pobožnost poznega srednjega veka in začetka novega veka, opozorile na tesno povezanost med teksti in ilustracijami, saj je pri nekaterih molitvah (najpogosteje pri odpustkovnih) izrecno navedeno, da morajo biti moljene pred ustrezno podobo. ${ }^{4}$

2 Brant je ta molitvenik mogoče začel snovati že pred letom 1494, prvič pa je bil njegov prevod iz latinščine v nemščino objavljen leta $1502 \mathrm{v}$ Strasbourgu. Za pregled problematike in starejše literature gl. Schoch (Dürer. Buchillustrationen, 2004, 79-85).

3 Tekstovno jih je najtemeljiteje raziskal Haimerl (1952, 123-149).

4 Gl. Heimerl $(1952,128)$; posebno pa dele poglavja o funkciji podob v pobožnostnih praksah pri Noll (2004, 47-69). 


\section{Hortulus animae iz leta 1516}

$\mathrm{Z}$ vseh teh vidikov je ljubljanski latinski Hortulus animae idealen predstavnik zgodnjenovoveškega predreformacijskega molitvenika. V usnje vezan molitvenik z 191 listi je, kot nam sporočata naslovnica in kolofon na koncu molitvenika, leta $1516 \mathrm{v}$ Mainzu natisnil Johannes Schöffer. ${ }^{5}$ Uporaba latinščine v tem času za takšen tip izdaje ni bila samoumevna, je pa bila med izobraženimi uporabniki pogosto bolj zaželjena. $\mathrm{V}$ NUK-ovem molitveniku so njegovi lastniki in uporabniki pustili veliko sledi, iz katerih lahko razberemo nekaj o njihovem poreklu in izobrazbi. Med več podpisi lastnikov na naslovnici jih je danes zaradi manjkajoče prednje platnice veliko poškodovanih do neberljivosti, dovolj dobro pa je ohranjen podpis na dnu strani: Joannes A(?)... pl / 158 ? (slika 1). Črki za imenom verjetno predstavljata ostanek besede "plebanus« (spodnji desni rob naslovnice je odtrgan), torej je bil po poklicu župnik, berljive prve tri številke pa kažejo na to, da je prišel v posest molitvenika v osemdesetih letih 16. stoletja. Janez je najverjetneje avtor nekaterih dopisov, ki so morali nastati v tem času, recimo zapisa o sklepu Tridentinskega koncila ob Andrejevi pridigi (neoznačen folij [k iii verso]). Iz višjih družbenih plasti je bil tudi neznani lastnik, ki se je ovekovečil s svojim grbom na notranji strani zadnje platnice (slika 2). Kakovostna celostranska grbovna kompozicija je narisana s peresom in je delo šolanega umetnika, naročnik ali kateri od naslednjih lastnikov pa je dodal nekaj napisov. Kljub večjim poškodbam na desni strani platnice je grb še dobro viden. Grbovni ščit je razdeljen diagonalno, na spodnjem delu so le vitice, na zgornjem pa lev s čašo $v$ desni šapi. Ta grbovna kompozicija se ponovi tudi na perutih v okrasu čelade, ki stoji nad ščitom. Med ščitom in šlemom je napisni trak, okoli grba pa se vijejo trakovi šlemnega ogrinjala. Pod grbom je narisano še kronano srce, prebodeno s strelico in položeno na cvet. Grb do sedaj še ni bil prepoznan, delno berljiv napis pa lahko beremo kot: Georgisis ... Lastnik je bil torej plemiškega rodu, glede na obliko grba in slogovne značilnosti risbe pa bi lahko šlo za enega prvih lastnikov. Kakovostni neznani risar si je zelo verjetno pomagal z lesorezno predlogo iz južnonemškega prostora, saj je risba zelo blizu lesorezu z grbom doktorja Hansa Gastgeba, le da je obrnjena zrcalno (slika 3). Lesorez ni datiran, prvotna atribucija Albrechtu Dürerju pa je bila upravičeno zavrnjena. ${ }^{6}$ Posredno ga tako lahko datiramo predvsem zaradi vidnega naslona na Dürerjeve heraldične lesoreze in bakroreze, ki so nastajali predvsem konec drugega in v začetku tretjega desetletja 16. stoletja. Nastanek Gastgebovega grba lahko tako postavimo v sredino dvajsetih let, nekoliko za tem pa bi lahko že nastala ljubljanska risba.

5 Oldenbourg $(1973,45)$, z oznako L 64, kjer ljubljanski izvod ni omenjen. Za Johanna Schöfferja gl. str. 88.

6 Dürerju je ta sicer zelo kakovosten lesorez pripisal Adam Bartsch. Ta atribucija je bila zavrnjena že ob izdaji njegovega slikovnega kataloga (Illustrated Bartsch, 10, 316); v zadnjem velikem katalogu Dürerjevega lesoreznega opusa pa ni vključen niti v popis napačno pripisanih del (Dürer. Holzschnitte, 2002). 


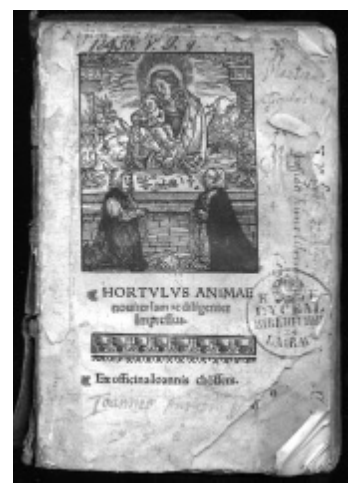

slika 1: Hortulus animae, 1516, NUK, naslovnica vir: foto NUK

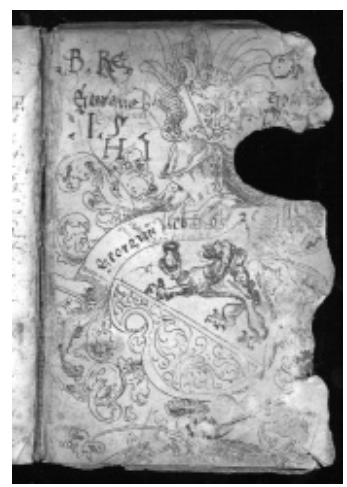

slika 2: Hortulus animae, 1516, NUK, grb na notranji strani zadnje platnice vir: foto NUK

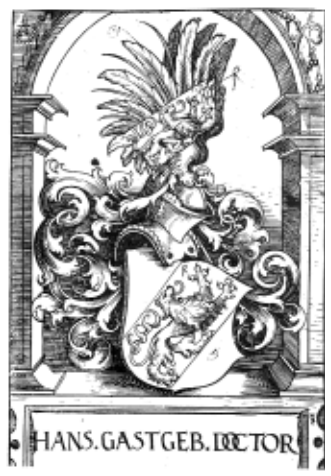

slika 3: Grb doktorja Gastgeba, Illustrated Bartsch 10, 1980, 316 vir: Fototeka Oddelka za umetnostno zgodovino FF UL 
Omenjeni podatki o lastnikih so zanimivi tudi zaradi dokazljivo presenetljivo dolge neprekinjene uporabe tega molitvenika, praktično do 17. stoletja, žal pa nam ne povedo veliko o njegovem izvoru. Glede na žig na naslovnici je bil vsaj od 19. stoletja v lasti ljubljanske Licejske knjižnice, kdaj točno pa je prišel na Slovensko, lahko samo ugibamo. Za razliko od številnih drugih izdaj je obravnavani mainški izvod lokalno dokaj nezaznamovan in bi bil lahko povsem primeren tudi za kranjske uporabnike. $\mathrm{V}$ posameznih tiskarskih središčih so namreč praviloma močneje izpostavljali najpomembnejše lokalne svetnike, $v$ primeru Mainza pa so to bili splošno znani in priljubljeni svetniki s sv. Martinom kot zavetnikom škofije na čelu.

Lesorezne ilustracije so glede na slogovne značilnosti vse delo enega mojstra, ki sicer po imenu ni znan, po kakovosti pa ga lahko umestimo med boljše lesorezce svojega časa. Posamezne ilustracije so bile tudi kolorirane (predvsem $\mathrm{z}$ rdečo in zeleno barvo), vendar bi glede na površnost nanašanja barv to lahko naknadno storil eden od lastnikov. O njihovi kakovosti priča poizkus pripisa avtorstva Dürerjevemu učencu Hansu Springinkleeju, kar pa je bilo upravičeno zavrnjeno (Hollstein. Springinklee, 2010, 188-189). Serija kaže na solidno šolanega, vendar izredno eklektičnega mojstra, saj se je skoraj pri vsaki ilustraciji posluževal grafičnih predlog pomembnejših nemških umetnikov (Oldenbourg, 1973, 93-95). Med številnimi predlogami želim izpostaviti serijo apostolov Lukasa Cranacha st. za ilustracije z apostoli (slika 4, 5, 6) ter številne lesoreze Albrechta Dürerja, med katerimi sta na področju knjižne ilustracije posebno pomembni seriji, ki ju je v prvih letih 16. stoletja izdelal za molitvenik Salus animae in neizdano pobožnostno knjigo (slika 7,8$).{ }^{7} \mathrm{Ne}$ glede na enotno avtorstvo je tako končni učinek podobno heterogen kot v primeru številnih drugih izdaj, kjer je med seboj pomešanih več različnih serij.

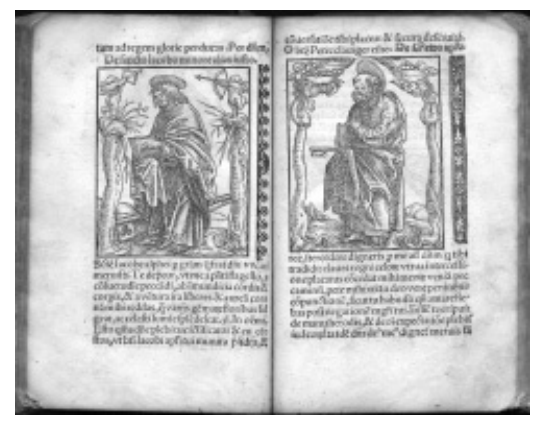

slika 4: Hortulus animae, 1516, NUK, sv. Jakob Mlajši in sv. Peter vir: foto NUK

7 Trenutno se večina raziskovalcev sicer nagiba proti atribuciji Dürerju, s čimer pa se sam ne strinjam. $\mathrm{Za}$ argumente proti Dürerju gl. Scherbaum, A., Gebetbuch in Andachtsbuch mit Sonntagsevangelien, v: Dürer. Buchillustrationen (2004, 494-523); za Dürerjevo avtorstvo gl. Cerkovnik (2010, 42-74); oba s pregledom starejše literature. 


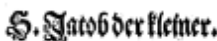

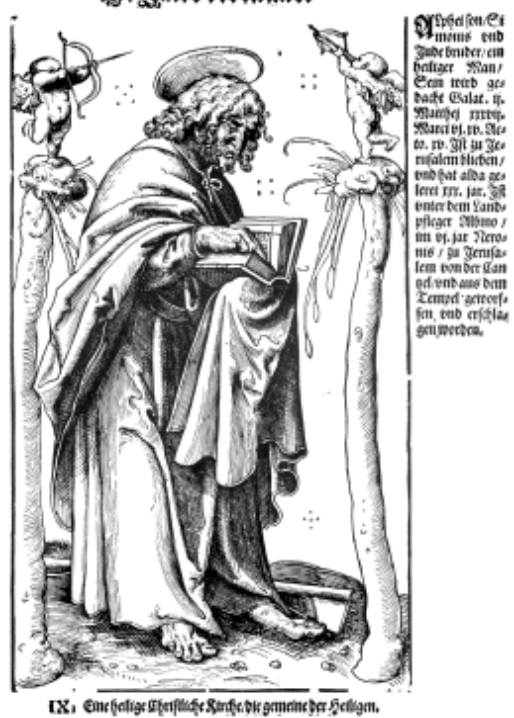

slika 5: Lucas Cranach st., sv. Jakob Mlajši, Illustrated Bartsch 11, 1980, 350 vir: Fototeka Oddelka za umetnostno zgodovino FF UL

\$. ชุctrut.

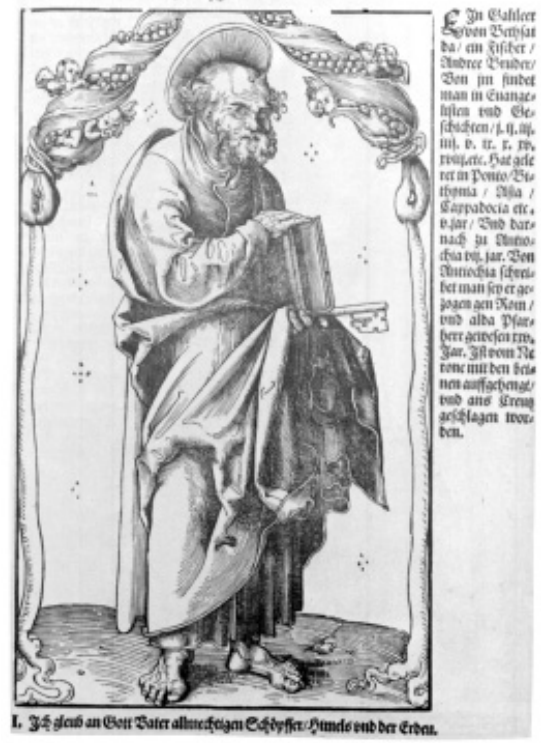

slika 6: Lucas Cranach st., sv. Peter, Illustrated Bartsch 11, 1980, 342 vir: Fototeka Oddelka za umetnostno zgodovino FF UL 


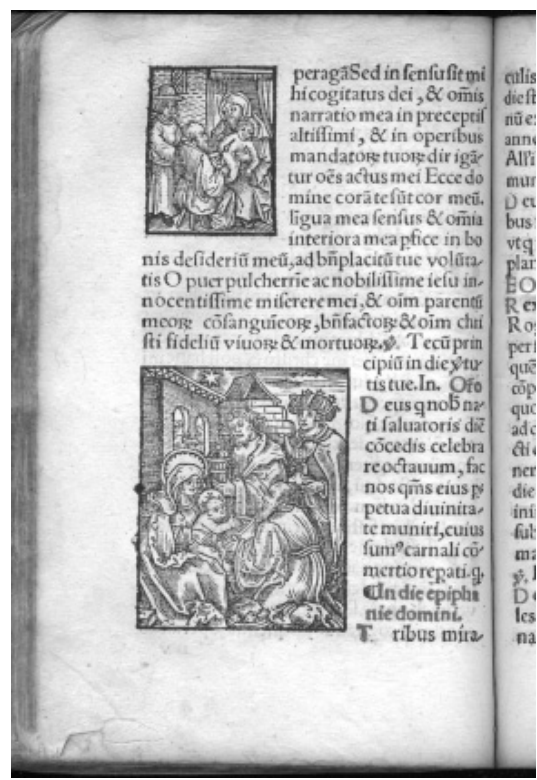

slika 7: Hortulus animae, 1516, NUK, Obrezovanje in Poklon sv. Treh kraljev vir: foto NUK

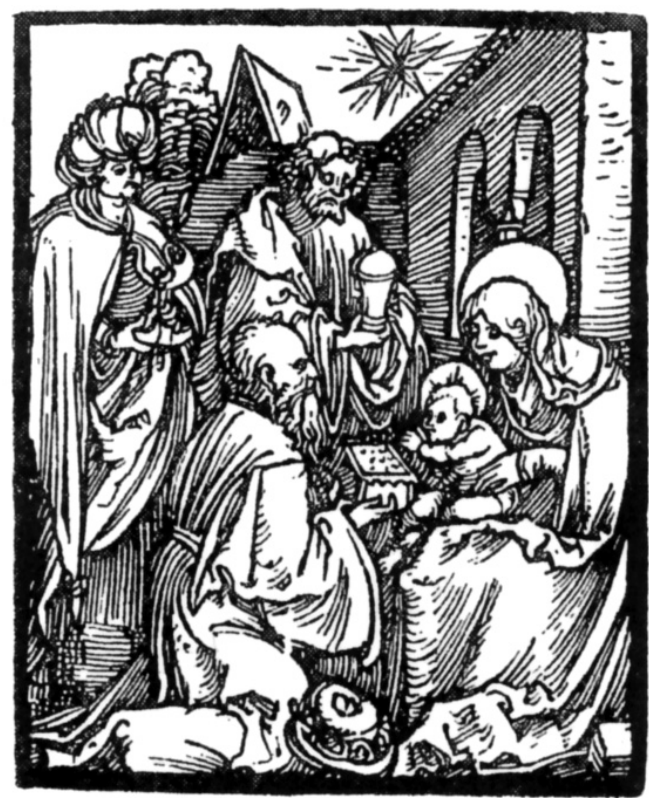

slika 8: Albrecht Dürer, Poklon sv. Treh kraljev za neizdano pobožnostno knjigo, Dodgson, 1909, tablica I vir: foto NUK 
Tipičen je tudi odnos med teksti in ilustracijami. Že njihovo število priča o pomenu, ki so ga imele v pobožnosti tega časa, čeprav molitve tega ne predpisujejo. S tega vidika so zato posebno zanimive molitve, ki od vernika zahtevajo, da jih moli pred ustrezno podobo, in jih seveda najdemo tudi tu. To sta molitvi sv. Gregorja Velikega in sv. Ane, obe obdarjeni z visokimi odpuski, če sta bili izrečeni pred ustreznima podobama (fol. e v recto-e verso; $n$ verso- $n$ ii recto). $V$ tem primeru sta ob obeh molitvah uporabljeni ustrezni ilustraciji, hiter pregled ilustracij, ki se ob takih molitvah pojavljajo v drugih izdajah, pa pokaže, da je bil odnos do podob dokaj sproščen. Podobne molitve praviloma ne narekujejo, kakšna naj bi ta podoba točno bila: Gregorjeva molitev je vezana na Čudežno mašo sv. Gregorja Velikega, v molitvenikih pa se lahko poleg upodobitve tega dogodka pojavlja tudi samostojna podoba tega cerkvenega učitelja ali pa Imago pietatis, torej Kristus trpin. Primer podobne ikonografske odprtosti najdemo tudi v ljubljanskem izvodu, saj je edini ponovljeni lesorez, ki prikazuje Štirinajst priprošnjikov v sili, uporabljen tako ob ustrezni molitvi kot tudi pri molitvi k sv. Nikolaju, saj je ta svetnik na ilustraciji najbolj izpostavljen (fol. l v verso, m v verso).

\section{Hortulus animae iz leta 1548}

Medtem ko prvi molitvenik glede na skoraj nepregledno ohranjeno število različnih izdaj v strokovni literaturi razumljivo ni bil deležen posebne pozornosti, to za drugega ne drži. Kot sem že omenil, fizično ta molitvenik bistveno ne odstopa od starejših, ki so nastali pred pojavom protestantizma. Knjižica v oktavu je vezana v usnje in vsebuje 176 potiskanih listov. Lesorezne ilustracije niso kolorirane, posamezne iniciale in deli teksta pa so natisnjeni z rdečo barvo (slika 9). Vzroke za večje zanimanje strokovnjakov za wittenberški molitvenik lahko tako iščemo v dejstvu, da je zlata doba molitvenikov $\mathrm{v}$ času nastanka te knjižice, posebej kar se tiče številčnosti izdaj, že minila. Še bolj pa je seveda pomembno dejstvo, da ga je uredil in izdal Georg Rhau, ki je bil povezan z najpomembnejšimi predstavniki nemškega protestantizma tega obdobja, ${ }^{8}$ in da je del ilustracij prispeval Lukas Cranach st. s svojo delavnico.

V uvodu Rhau molitvenik posveča svojim hčerkam, Anni, Christini, Catharini, Otilii in Marghareti, ki so se mu rodile v prvem in drugem zakonu (fol. A ii recto-A v verso). Kot ljubeči oče jim je pripravil zbirko protestantskih interpretacij najpomembnejših krščanskih molitev in teoloških tekstov, ki naj jih vodijo do zveličanja, ko jih ne bo več mogel voditi sam. Kot napoveduje Cranachova ilustracija $\mathrm{z}$ upodobitvijo Kristusa $\mathrm{z}$ otročiči, se Rhau sklicuje na dogodek, opisan v Markovem evangeliju, ko so apostoli poskušali otrokom preprečiti, da bi prišli do Kristusa, ta pa jim je rekel: „Lasset die Kindlin zu mir komen / und weret in nicht / Denn solcher ist das Reich Gottes« (fol. A ii verso) -

8 Georg Rhau je danes znan predvsem zaradi izdajanja protestantskih glasbenih tiskov (Geck, 2005; Reske, 2007, 997-998). 
(»Pustite otroke, naj prihajajo k meni, in ne branite jim, kajti takšnih je Božje kraljestvo.« $[\mathrm{Mr} 10,14])$ (slika 10). Rhau v tem prepoznava opozorilo na pomen neposrednega stika otrok s Kristusom in tudi odgovornost staršev, da jih do njega privedejo. To misel - torej pomen neposrednega stika z Bogom - poudarjajo tudi nadaljnji teksti in interpretacije svetih besedil, ki sta jih poleg Rhaua spisala Martin Luter in Philipp Melanchthon.

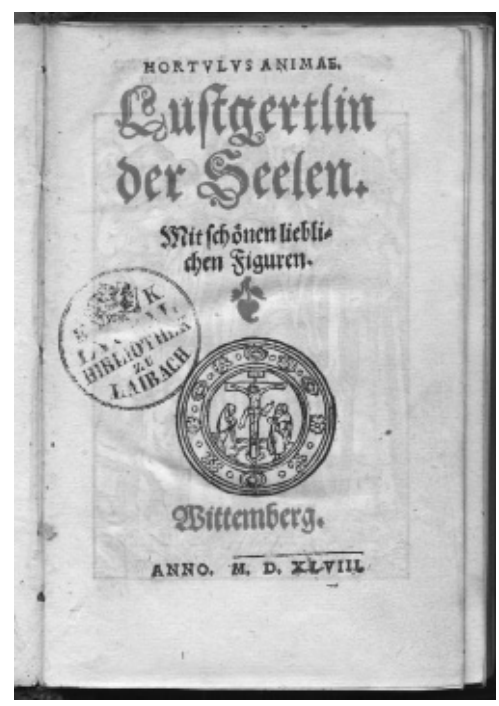

slika 9: Hortulus animae, 1548, NUK, naslovnica vir: foto NUK

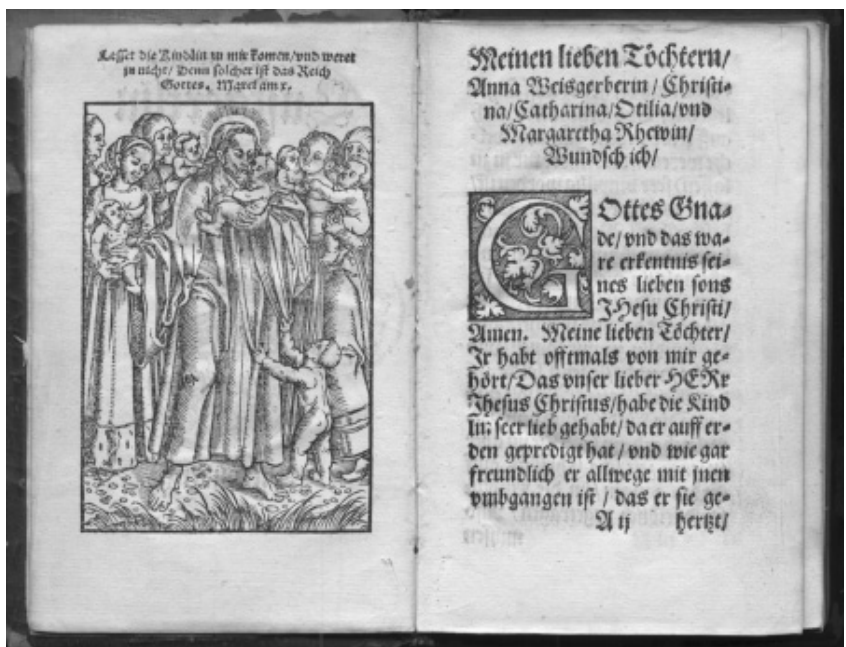

slika 10: Hortulus animae, 1548, NUK, Kristus med otroki vir: foto NUK 
Naslednji večji sklop besedila je namenjen komentirani Izpovedi vere, ki je razdeljena na posamezne verze, vsakega pa spremlja majhna ilustracija ustreznega apostola (fol. B viii recto-L iiii verso) (slika 11). Povezavo posameznih verzov Vere $\mathrm{z}$ apostoli lahko navežemo na starejšo krščansko tradicijo, ki je dobro znana tudi pri nas, saj se je tega ikonografskega principa posluževal tudi zasilno poimenovani Mojster Apostolskih mučeništev, ki je sredi 15. stoletja poslikal več cerkva na Slovenskem (Höfler, 1976). Glede protestantskega razumevanja odnosa do ilustracij oziroma podob na splošno je najpomembnejši teološki tekst o čaščenju svetnikov (»Von anrufen der Heiligen«; fol. P iiii v in dalje). Po tem tekstu je edini pravi posrednik med Bogom Očetom in verniki Kristus, obračanje na svetnike pa je ljudi vse prepogosto zavedlo, da niso molili naravnost $\mathrm{k}$ Bogu, zato se morajo protestanti ogibati molitvam, namenjenim svetnikom. Posledica tega je vsakršna odsotnost molitev in podob svetnikov in svetnic, ki niso neposredno povezani s Kristusom - med temi pa so bili očitno samo apostoli in sv. Janez Krstnik.

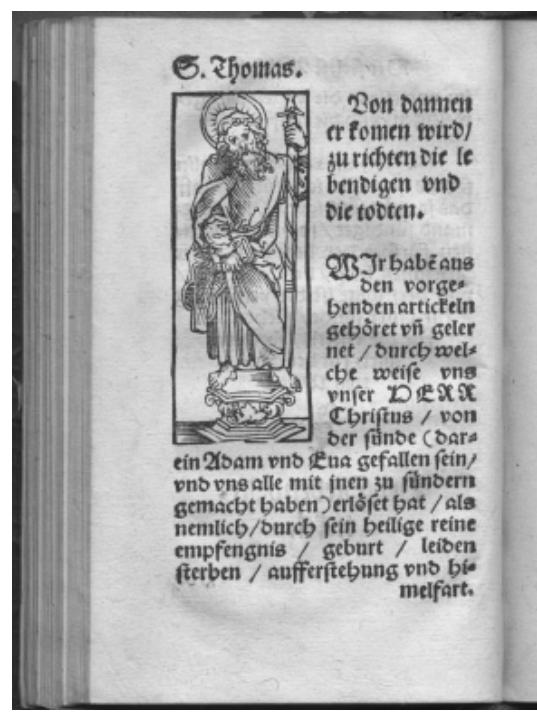

slika 11: Hortulus animae, 1548, NUK, Sv. Tomaž vir: foto NUK

Posebno nelagodje je očitno spremljalo upodobitve Marije, ki nikoli ni upodobljena sama, temveč vedno v povezavi s Kristusom, v omenjenem tekstu pa je izrecno poudarjena zapoved: "Die Jungfrawen Mariam sol man nicht anrufen.«, torej da k Devici Mariji ne smeš moliti (fol. Q iiii r). Ne glede na to Marijine upodobitve dokazujejo, da med protestanti nikakor ni izgubila vse veljave. Kot v svoji študiji o Marijinem kultu v Nemčiji tega časa opozarja Bridget Heal, je prav ilustracija, uporabljena $\mathrm{v}$ tem molitveniku, primer, kako so se protestanti spoprijeli 
s problemom sprejemanja predreformacijskih podob, posebno Marijinih. Ključna v tem procesu je bila reinterpretacija Marije iz nebeške posredovalke v materinsko vlogo (»Hausmutter«) (Heal, 2009, 94).

S poudarjeno materinsko vlogo Marije lahko povežemo tudi poudarek na upodabljanju Jezusa kot otroka. Čeprav je seveda Kristus na več ilustracijah upodobljen v različnih obdobjih svojega odraslega življenja, posebno izstopata dve upodobitvi Jezusa kot stoječega golega dečka $\mathrm{z}$ vladarskim jabolkom (fol. Q vi recto, $\mathrm{R}$ iii recto). Kot v primeru podobe Marije je tudi tu prišlo do reinterpretacije veliko starejšega motiva. Take upodobitve so bile značilne za samostojne, na papir natisnjene božične pozdrave, ki so si jih podarjali ljudje od 15. stoletja naprej (torej prednice današnjih božičnih voščilnic), za protestante pa je ta upodobitev predstavljala Boga, ki ne pride do vernikov v grozi, temveč kot fantič, ki ga vsak lahko ljubkuje (Koepplin, 1983, 358359).

Rhauov molitvenik tako v primerjavi z predreformacijskimi deluje veliko bolj fundamentalistično, tako pri številu in raznolikosti teksta kot pri ikonografskih motivih ilustracij. Ob vseh razlikah se postavlja vprašanje, zakaj je Rhau za svoj molitvenik izbral naslov molitvenika, ki je tako rekoč kompendij vsega, kar so protestanti očitali predreformacijski pobožnosti. Na to vprašanje je $\mathrm{z}$ vidika zgodovinskih okoliščin najbolje odgovoril Erik Hühns, ki je opozoril, da je Rhau pri tem sledil Lutru; hitro je namreč opazil medijsko moč teh knjižic in jih poskušal čim prej integrirati v novo religijo (Hühns, 1977, 66). Wittenberška verzija je bila očitno pri tem zelo uspešna, saj je bil molitvenik večkrat ponatisnjen. ${ }^{9}$ Kljub previdnosti pri uporabi svetih podob že napis pod naslovom na naslovnici, »Mit schönen lieblichen Figuren« (»Z lepimi ljubkimi figurami«), dokazuje, da se tudi protestanti s svojimi ikonoklastičnimi težnjami niso mogli upreti dražu predvsem predreformacijskih likovnih upodobitev in so se, kot ugotavlja Healova, zavedali tudi njihove pedagoške in medijske vrednosti (Heal, 2009, 94). Tako ni presenetljivo, da je večino ilustracij oskrbel najpomembnejši protestantski umetnik tega časa Lukas Cranach st. s svojo delavnico. Med temi prevladujejo Cranachove ilustracije za knjižno izdajo relikvij in relikviarijev wittenberške stolnice iz leta $1509^{10}$ - torej za propagiranje ene od s strani protestantov najbolj preziranih predreformacijskih navad. Uporabljene upodobitve relikviarijev, ki so bili v času izdaje molitvenika sicer že uničeni, lahko razumemo v podobnem kontekstu kot pri upodobitvi Marije - torej v razvrednotenju prvotnega pomena in postavitvi v nov, protestantski kontekst. ${ }^{11}$

9 Različne izdaje so naštete pri Zimmermann (1929, 31 in naprej; Hühns, 1977, 64). V primeru ljubljanskega izvoda gre mogoče celo za redko prvo izdajo v formatu oktava (Koepplin, Falk, 1974, 398).

10 Za ta projekt Friderika Saškega gl. Cárdenas (2002).

11 O tem posebno Koepplin, Falk (1974, 395-396). 
Poleg ilustracij iz wittenberške knjige svetinj in drugih lesorezov Lukasa Cranacha st. in njegove delavnice je del ilustracij prispeval z monogramom podpisani mojster A W. ${ }^{12}$ Neznani saški mojster je že konec dvajsetih let 16 . stoletja sodeloval pri Rhauovih knjižnih projektih, iz katerih je tudi večina $\mathrm{v}$ molitveniku uporabljenih ilustracij. Praviloma gre za večje narativne prizore iz Kristusovega življenja. Medtem ko Cranachove ilustracije razumljivo ne kažejo nobenih protestantskih ikonografskih rešitev, je pri monogramistu A W to že drugače. V molitveniku najdemo za protestante značilno upodobitev Križanja, kjer je v ozadju levo od križa upodobljeno Abrahamovo žrtvovanje Izaka, desno pa Bronasta kača (fol. P verso). ${ }^{13} \mathrm{Z}$ lesorezi istega mojstra je ilustriran poseben dodatek na zadnjih 18 listih knjižice. Gre za »Das Snmbo.lum der heiligen Aposteln / darin der grund unsers Christ=lichen Glaubens gelegt ist / « Martina Lutra, ki je bil prav tako natisnjen leta 1548 v Wittenbergu in okrašen »Mit schönen liebli=chen Figuren « (fol. A-C). V tem tekstu gre za že omenjeni princip razširjene molitve Izpovedi vere, ki se navezuje na apostole - sam tekst je bil pogosto dodatek temu Hortulu, sicer pa je kot samostojni tisk izšel že leta $1539 .{ }^{14}$ Večina ilustracij, med katerimi je nekaj ponovljenih iz prejšnjega dela, je označenih z njegovim monogramom, na ilustraciji s Spovedjo pa je tudi letnica 1536, ko je očitno nastala celotna serija (fol. $B$ vii verso). $Z$ vidika protestantske ikonografije je poleg Križanja (fol. A vi verso) posebna samo upodobitev Bogoslužja, kjer je po protestantskih liturgičnih pravilih $\mathrm{v}$ ospredju prižnica (fol. B v verso) (slika 12).

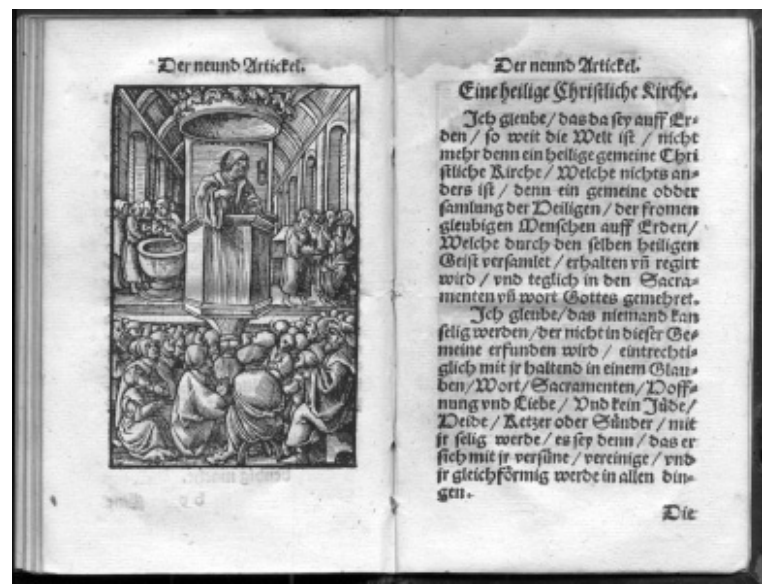

slika 12: Hortulus animae, 1548, NUK, Bogoslužje vir: foto NUK

12 Kot veliko drugih neidentificiranih mojstrov tudi monogramist A W ni bil deležen večje pozornosti umetnostnih zgodovinarjev; gl. Vollmer (1950, 377), Schmidt (2011).

13 Taka oblika Križanja se navezuje na motiv Postave in milosti, ki ga je na primeru študije o koroških in štajerskih protestantskih nagrobnikih pri nas dobro predstavila Daša Pahor (2006). 
Oba v Ljubljani hranjena molitvenika tako predstavljata dva različna pola $\mathrm{v}$ dojemanju pobožnosti, ki pa se poslužujeta istih metod za dosego istega cilja - doseči in nagovarjati čim večje število vernikov. 


\section{Viri}

Hortulus animae, Maguntie (izd. Johannes Schöffer) 1516; NUK, Ljubljana, Zbirka redkih tiskov, GS 012950.

Hortulus animae. Lustgertlin der Seelen. Mit schönen Lieblichen Figuren, Wittemberg (izd. Georg Rhau) 1548; NUK, Ljubljana, Zbirka redkih tiskov, GS 013829.

\section{Literatura}

Albrecht Dürer. Das druckgraphische Werk. Band II. Holzschnitte und Holzschnittfolgen (ur. Schoch, R., Mende, M., Scherbaum, A.), München, Berlin, London, New York 2002.

Albrecht Dürer. Das druckgraphische Werk. Band III. Buchillustrationen (ur. Schoch, R., Mende, M., Scherbaum, A.), München, Berlin, London, New York 2004.

Cárdenas, L., Friedrich der Weise und das Wittenberger Heiltumsbuch. Mediale Repräsentation zwischen Mittelalter und Neuzeit, Berlin 2002.

Cerkovnik, G., Lesorezne ilustracije nemških tiskanih molitvenikov poznega 15. in zgodnjega 16. stoletja: pomen in vpliv $v$ drugih likovnih medijih, doktorska disertacija, Ljubljana: Filozofska fakulteta 2010.

Dodgson, C., Holzschnitte zu zwei nürnberger Andachtsbüchern aus dem Anfange des XVI. Jahrhunderts, Berlin 1909.

Geck, M., pod geslom: Rhau, v: Die Musik in Geschichte und Gegenwart: allgemeine Enzyklopädie der Musik. Personenteil 13 (ur. Finscher, L.), Kassel in drugje 2005, stolpci 1611-1615.

Haimerl, F. X., Mittelalterliche Frommigkeit im Spiegel der Gebetbuchliteratur Süddeutschlands, München 1952.

Heal, B., The cult of the Virgin Mary in early Modern Germany: Protestant and Catholic Piety, 1500-1648, New York 2009 (prva izdaja 2007).

Höfler, J., Zum ehemaligen Zwölfbotenaltar aus Wiener Neustadt, v: Österreichische Zeitschrift für Kunst und Denkmalpflege 30, 1976, str. 163-172.

Hollstein's German Engravings, Etchings and Woodcuts 1400-1700. Volume LXXVI. Hans Springinklee. Part II (ur. Beaujean, D., Schoch, R.), Oudekerk aan den Ijssel 2010.

Hühns, E., Der »Hortulus animae« - ein Frühdruck in der Bibliothek des Märkischen Museums v: Jahrbuch des Märkischen Museums 3, 1977, str. 65-68.

The Illustrated Bartsch 10. Sixteenth Century German Artists. Albrecht Dürer (ur. Falk., T.), New York 1980. 
The Illustrated Bartsch 11. Sixteenth Century German Artists. Hans Burgkmair, the Elder. Hans Schäufelein. Lucas Cranach, the Elder (ur. Falk., T.), New York 1980.

Koepplin, D., Reformation der Glaubensbilder: Das Erlösungswerk Christi auf Bildern des Spätmittelalters und der Reformationszeit, v: Martin Luther und die Reformation in Deutschland (ur. Gerhart Bott), 25. junij - 25. september 1983 Germanisches Nationalmuseum Nürnberg, str. 333-378.

Koepplin, D., Falk, T., Lukas Cranach. Gemälde, Zeichnungen, Druckgraphik. Band I, Basel, Stuttgart 1974.

Noll, T., Albrecht Altdorfer in seiner Zeit. Religiöse und profane Themen in der Kunst um 1500, München, Berlin 2004.

Oldenbourg, M. C., Hortulus animae [1494]-1523. Bibliographie und Illustration, Hamburg 1973.

Pahor, D., Motiv Postave in milosti v sepulkralni umetnosti poznega 16. stoletja na Štajerskem in Koroškem, v: Acta historiae artis Slovenica 12, 2006, str. 29-42.

Reske, C., Die Buchdrucker des 16. und 17. Jahrhunderts im deutschen Sprachgebiet (Auf der Grundlage des gleichnamigen Werkes von Josef Benzing), Wiesbaden 2007.

Schmidt, H. M. in drugi, Masters, anonymous, and monogrammists, v: Grove Art Online. Oxford Art Online, http://www.oxfordartonline.com/subscriber/article/ grove/art/T055065pg413 [19.9. 2011].

Vollmer, H., Allgemeines Lexikon der bildenden Künstler (Thieme-Becker) 37. Meister mit Notnamen und Monogrammisten, Leipzig 1950.

Zimmermann, H., Lukas Cranach d. Ä. Folgen der Wittenberger Heiligtümer und die Illustrationen des Rhau'schen Hortulus animae, Halle 1929. 


\title{
Hortuli animae from the Years 1516 and 1548 in the Collection of the National and University Library of Liubljana: The Pre-Reformation Prayer Book and its Lutheran Transformation
}

\begin{abstract}
Keywords: Hortulus animae, National and University Library of Ljubljana, woodcut illustrations, pre-Reformation piety, Protestant piety, Lucas Cranach the Elder, Georg Rhau
\end{abstract}

The collection of rare prints at the National and University Library of Ljubljana contains two small printed prayer books entitled Hortulus animae. One is from 1516 and the other from 1548, and both are embellished with numerous woodcut illustrations. On closer inspection, the similarities between the booklets soon vanish: the older one belongs to the golden age of pre-Reformation prayer books of the first two decades of the sixteenth century, and the second one to the Reformation. Nevertheless, both examples have so far been ignored by scholars.

The Latin prayer book dated 1516 was published in Mainz by Johann Schöfer. It belongs to the important and numerous group of pre-Reformation prayer books, among which Hortulus animae was most successful. This type derives from books of hours, with adjustments to central European devotional practices. Hortulus animae is a compendium of diverse devotional texts designed to equip Christians for every situation in which they might need divine assistance. An important role was also played by numerous illustrations, as proven by some prayers that explicitly demand recitation before a specific image (the prayers of St. Gregory the Great and St. Anne). The importance of these booklets is confirmed by the importance of some of the artists that provided illustrations, such as Albrecht Dürer, Hans Burgkmair the Elder, and Hans Holbein the Younger. The illustrations in the Ljubljana prayer book were all executed by a single master, which was not common for this type of publication. His name and his other works are unknown, although the quality of his woodcuts surpasses many in other series used at this time. The special value of this prayer book also lies in numerous traces left by its owners, the most impressive being the drawing of the coat of arms on the back cover. 
The second Hortulus animae with German text was published in Wittenberg in 1548 by the important Protestant publisher Georg Rhau. The texts, partly written by Martin Luther and Philipp Melanchthon, show crucial differences from their pre-Reformation predecessor. Although richly illustrated with Lucas Cranach's preReformation woodcuts for a Wittenberg relics collection book from 1509, their meaning did not remain the same. Luther was very aware of the power of images, specially over the less educated. His teachings are perfectly expressed in this prayer book. The images of saints are limited to Christ's family, the twelve apostles, and John the Baptist, and several points in the text are equipped with a warning against idolatry. The smaller group of illustrations depicting specific Reformation subjects was contributed by a younger anonymous artist known only by his monogram, $A W$.

Each in its specific historical context, both prayer books are therefore a valuable document of pre-Reformation and Reformation piety in central Europe of the first half of the sixteenth century. 